\title{
Strategi Pengembangan Usaha Kecap Cemara \\ Dengan Metode Blue Ocean Strategy dan Balanced Scorecard Pada UKM Cemara Food, Kecamatan Talun, Kabupaten Blitar
}

\section{Business Development Strategy of Cemara Soy Sauce With The Methods of Blue Ocean Strategy and Balanced Scorecard on Cemara Food Small Medium Enterprise, Talun District, Blitar Regency}

\author{
Tio Wahyu Nugraha ${ }^{1 *}$, Dina Novia Priminingtyas ${ }^{2}$ \\ Jurusan Sosial Ekonomi, Fakultas Pertanian, Universitas Brawijaya, Jl. Veteran Malang 65145, Jawa \\ Timur, Indonesia.
}

Diterima: 25 Juli 2016; Direvisi: 26 Juli 2016; Disetujui: 29 Juli 2016

\begin{abstract}
ABSTRAK
Meningkatnya jumlah pesaing menyebabkan UKM Cemara Food seakan terjebak dalam kondisi persaingan yang sangat kompetitif karena kompetisi pasar. Minimnya inovasi dalam hal manajerial produksi dan operasi membuat strategi yang diterapkan perusahaan menjadi tidak relevan lagi dengan kondisi yang ada. Sehingga diperlukan penelitian ini untuk melihat kondisi kinerja perusahaan. Tujuan dilakukan penelitian ini adalah untuk 1) Menganalisis kinerja UKM Cemara Food. dan 2) Memformulasikan rancangan strategi pengembangan untuk produk kecap Cemara. Metode yang digunakan untuk menganalisis kinerja perusahaan adalah Balanced Scorecard, sedangkan untuk memformulasikan strategi menggunakan pendekatan Blue Ocean Strategy dan Balanced Scorecard. Nilai R/C Ratio sebesar 1,25 dan ROE sebesar 16,4\% menunjukan penggunaan modal dan aliran keuangan perusahaan sudah dapat dikatakan baik meski harus ditingkatkan lagi efisiensinya. Nilai CSI sebesar $71 \%$ yang berarti bahwa indeks kepuasan keseluruhan konsumen yang dihitung berdasarkan atribut produk berada pada kriteria puas.
\end{abstract}

Kata Kunci: blue ocean strategy; balanced scorecard; kecap; UKM

\begin{abstract}
The increasing number of competitors cause Cemara Food Small Medium Enterprise (SMEs) seemed stuck in a state of bloody competition for market competition. The lack of innovation in terms of production and operation managerial strategies applied to make the company become irrelevant with existing conditions. So, we need this research to describe the condition of the company's perfomance. The purpose of this research is to 1) to analyze the performance of Cemara Food company and 2) formulating the development strategy of soy product of Cemara soysauce. The method used to analyze the company's performance is the Balanced Scorecard, while to formulate a strategy of using approaches Blue Ocean Strategy and Balanced Scorecard. The rate of $R / C$ ratio of 1.25 and a ROE of $16.4 \%$ showing the use of capital and financial flows are good, although they had to improve more the efficiency. CSI value of 71\%, which means that the overall customer satisfaction index is calculated based on the criteria of product attributes are quite satisfy.
\end{abstract}

Keywords: blue ocean strategy; balanced scorecard; soysauce; SMEs

\section{Pendahuluan}

Sektor industri kecil melalui UKM merupakan salah satu bentuk strategi alternatif untuk mendukung pengembangan perekonomian dalam pembangunan jangka panjang di

"Penulis Korespondensi.

E-mail : tio20nugraha@gmail.com
Indonesia. Kinerja UKM haruslah selalu dievaluasi untuk tetap eksis menyesuaikan minat konsumen. Pentingnya sektor industrialisasi, utamanya pada industri kecil menengah sebagai penopang pembangunan membuat perlu adanya strategi alternatif pengembangan untuk menjaga eksistensi produk dan usaha. Untuk mencapai keberhasilan pembangunan ekonomi Indonesia melalui industrialisasi, utamanya pada sektor 
industri kecil menengah adalah dengan strategi pengembangan usaha. Strategi pengembangan penting untuk mendorong produk hasil industri agar memiliki daya saing yang lebih tinggi untuk masuk ke dalam pasar. Terlebih dengan pertumbuhan industri kecil yang bergerak di bidang olahan makanan dewasa ini begitu menjamur.

Oleh karena itu pelaku usaha dituntut untuk berinovasi dalam menghadapi persaingan pasar. Kerapatan persaingan industri kecap di Kabupaten Blitar menciptakan medan kompetisi yang diperebutkan oleh para pemain yang menawarkan produk dan pasar yang sama. Sejak tahun 1991 hingga 2015 pertumbuhan industri kecap di Blitar mengalami peningkatan. Kecap merek Cemara merupakan produk unggulan Cemara Food. Perusahaan yang berdiri sejak 1991 ini merupakan salah satu pelopor industri kecap di Kabupaten Blitar. Keadaan tersebut membuat UKM Cemara Food harus menghadapi persaingan yang ketat. Berdasarkan data Disperindag Kabupaten Blitar (2015) jumlah industri pembuatan kecap yang telah memiliki merek adalah sebanyak 7 unit usaha yaitu adalah kecap Cap Durian Mas, Cap Bajang, Kecap Jamburi, Kecap Rahayu, Kecap Gurami, Cap Tjapar, dan Kecap Cemara.

Kendala serta ancaman yang dihadapi Kecap Cemara adalah dikarenakan banyaknya jenis usaha yang sama di wilayah Kabupaten Blitar membuat kompetitor untuk segmentasi produk dan pangsa konsumen yang sama juga semakin sesak. Kondisi tersebut dapat dianalogikan bagai lautan persaingan usaha yang "berdarah-darah" (Red Ocean) karena kompetisi pasar. Masalah lain adalah permintaan tinggi hanya pada saat bulan-bulan dimana masyarakat di Blitar mengadakan upacara adat seperti pernikahan. Fluktuasi permintaan yang tidak dapat diprediksi membuat pola produksi perusahaan menjadi kacau. Seringkali perusahaan memproduksi kecap melebihi dari permintaan yang menyebabkan tingginya stok kecap di gudang. Terbatasanya wilayah pemasaran yang hanya di sekitar wilayah Kabupaten Blitar, Kediri, dan sebagian Malang Selatan membuat kelebihan produk di gudang tidak dapat tersalurkan sehingga memungkinkan terjadinya penurunan kualitas produk.

Untuk tetap eksis dan memenangkan persaingan, Cemara Food perlu melakukan inovasi dalam menciptakan ruang pasar baru. Fokus penelitian ini adalah untuk mengevaluasi kinerja industri kecil menengah dengan produk kecap Cemara milik UKM Cemara Food menggunakan metode Balanced Scorecard. Setelah didapatkan hasil evaluasi kinerja perusahaan, penelitian ini bertujuan untuk merumuskan strategi pengembangan usaha dengan menggunakan metode Blue Ocean Stategy.

\section{Metode Penelitian}

\subsection{Metode Penentuan Responden}

Metode penentuan responden yang digunakan oleh peneliti untuk produsen adalah menggunakan key informan yaitu produsen kecap Cemara Kabupaten Blitar. Penentuan responden yang digunakan peneliti untuk konsumen adalah menggunakan metode non probability sampling yaitu dengan quota sampling. Metode non probability sampling merupakan teknik penentuan sampel/responden yang tidak memberikan kesempatan yang sama bagi setiap unsur atau anggota populasi untuk dipilih menjadi sampel/responden penelitian, (Sugiyono, 2013).

Quota sampling merupakan teknik untuk menentukan sampel dari populasi yang mempunyai ciri-ciri tertentu sampai jumlah yang diinginkan oleh peneliti (Sugiyono, 2013). Dalam sampling kuota, ukuran serta sampel pada setiap sub-subpopulasi ditentukan oleh peneliti sampai jumlah tertentu.

Populasi utama yang juga menjadi kategori utama penelitian adalah konsumen yang mengetahui dan dan pernah mengkonsumsi kecap Cemara, kecap Bango dan kecap Gurami yang berdomisili di wilayah Kabupaten Blitar. Kemudian sub-populasi penelitian dibagi atas 2 subkategori yaitu ibu rumah tangga dan pedagang makanan. Peneliti menggunakan metode quota sampling karena dalam mengevaluasi kinerja, serta perumusan strategi dibutuhkan konsumen dari perusahaan pembanding. Sampel yang diambil adalah konsumen yang pernah mengkonsumsi kecap Cemara, kecap Gurami dan kecap Bango.

Ukuran penentuan jumlah responden penelitian karena ukuran populasi yang ada tidak dapat diketahu dengan pasti, sehingga peneliti menggunakan metode rumus Lemeshow dengan probability Bernoulli (Sedarmayanti, 2002).

$\mathrm{n}=\frac{\left[z_{\frac{\alpha}{2}}^{\alpha}\right]^{2} \cdot \rho}{\epsilon}$

Keterangan:

$\mathrm{n}=$ jumlah sampel 
$\mathrm{Z}=$ nilai yang didapat dari Tabel distribusi normal dengan peluang $\frac{\alpha}{2}$ ( 2 tailed $)$

$\rho=$ probabilitas populasi diambil sebagai sample $(50 \%)$

$\alpha=$ tingkat ketelitian

$\epsilon=$ tingkat kesalahan

Dalam penelitian ini digunakan tingkat ketelitian $(\alpha)$ sebesar 5\% dan tingkat kepercayaan sebesar 95\% sehingga diperoleh nilai $\mathrm{Z}=1,96$. Tingkat kesalahan $(\epsilon)$ telah ditentukan sebesar 5\%. Probabilitas populasi yang diambil sebagai sampel adalah sebesar $50 \%$. Apabila dilakukan perhitungan menggunakan rumus maka diperoleh jumlah sampel minimum sebesar :

$\mathrm{n}=\frac{[1,96]^{2} \cdot 0,5}{0,05}$

$\mathrm{n}=38,416$

Berdasarkan hasil perhitungan maka diperoleh jumlah sampel minimum sebesar 38,416 orang. Oleh karena peneliti menginginkan jumlah sampel dengan jumlah genap dan proporsi yang seimbang, maka peneliti menetapkan jumlah sampel sebanyak 40 orang. Kriteria dan jumlah responden penelitian ialah ibu rumah tangga sebanyak 20 orang dan pedagang makanan sebanyak 20 orang. Syarat masingmasing sub-kategori ialah merupakan konsumen yang pernah mengkonsumsi dan sedang menggunakan Kecap Cemara, Kecap Gurami dan Kecap Bango pada makanan/masakannya.

\subsection{Metode Pengumpulan Data}

Metode pengumpulan data di dalam penelitian ini menggunakan dua metode yaitu dengan data sekunder dan data primer. Data sekunder yang digunakan adalah data dari Badan Pusat Statistik mengenai pertumbuhan industri kecil menengah di kabupaten Blitar, profil perusahaan, rujukan penelitian referensi dari buku dan internet. Untuk pengumpulan data sekunder, peneliti menggunakan teknik dokumentasi. Metode pengumpulan data primer yang digunakan peneliti adalah dengan menggunakan teknik wawancara dengan bantuan media kuisioner dan juga melakukan observasi langsung.

Teknik wawancara yang dilakukan oleh peneliti adalah dengan mendatangi dan bertatap muka secara langsung dengan responden. Pelaksanaan wawancara dilakukan setelah adanya kesepakatan dengan responden untuk dilakukan wawancara agar tidak ada kesan keterpaksaan. Teknik ini juga bertujuan untuk mendampingi responden apabila terdapat pertanyaan yang kurang jelas. Teknik pengumpulan data melalui wawancara dalam penelitian ini, peneliti menggunakan kuisioner. Kuisioner digunakan oleh peneliti untuk mempermudah dalam mendapatkan informasi, dikarenakan di dalam kuisioner telah terdapat alternatif jawaban yang bisa dipilih oleh responden.

\subsection{Metode Analisis Data}

\subsubsection{Analisis Blue Ocean Strategy}

Metode analisis yang digunakan peneliti dalam perumusan strategi pengembangan menggunakan analisis Blue Ocean Strategy. Metode ini digunakan dengan tujuan untuk menciptakan industri kecap yang memenangkan kompetisi diantara produsen kecap yang ada. Pelaksanaan analisis menggunakan metode Blue Ocean strategy dilakukan dalam beberapa tahap yaitu :

\subsubsection{Strategy Canvas}

Kanvas strategi digunakan untuk mengetahui posisi produk kecap Cemara di dalam ruang pasar dengan pembanding produk kecap Gurame dan kecap Bango. Dengan menggetahui hasil dari kanvas strategy maka akan di dapatkan informasi terkait posisi kecap Cemara diantara pesaing-pesaingnya. Pengukuran kanvas strategi menggunakan skala likert. Skala likert digunakan untuk mengukur sikap, pendapat dan persepsi seseorang tentang sebuah fenomena, (Sugiyono, 2013). Skor skala likert yang digunakan dalam penelitian ini berjumlah lima angka yaitu: 5. Sangat Puas, 4. Puas, 3. Ragu-ragu, 2. Tidak Puas, 1. Sangat Tidak Puas.

Faktor-faktor yang digunakan untuk mengetahui letak kompetisi kecap Cemara diantara para pesaing-pesaingnya adalah hanya pada atribut harga, rasa, desain kemasan, volume kemasan, warna kecap, kekentalan, memberi keuntungan konsumen, kesesuaian produk dengan harapan konsumen, ketersedian produk, dan membuat makanan sedap.

\subsubsection{Kerangka Kerja 4 Langkah Blue Ocean Strategy}

Dalam perumusan strategi pengembangan berbasis Blue Ocean Strategy peneliti menggunakan kerangka kerja empat langkah sebagai indikator. Keempat kerangka kerja tersebut adalah sebagai berikut: 
a. Hapuskan

Hapus faktor-faktor yang telah diterima oleh perusahaan. Indikator faktor-faktor yang dihapus adalah faktor-faktor yang memiliki bobot paling rendah diantara faktor-faktor kompetisi lainya.

\section{b. Ciptakan}

Menciptakan faktor-faktor apa saja yang belum pernah ditawarkan oleh industri. Sehingga faktor-faktor tersebut juga belum ada pada perusahaan lain.

\section{c. Tingkatkan}

Meningkatkan faktor-faktor hingga di atas standar industri dan kompetisi pada samudera merah. Indikator dapat dilihat pada grafik yang saling bertemu dengan pesaing dari hasil analisis kanvas.

\section{d. Kurangi}

Mengurangi faktor-faktor hingga di bawah standar industri. Indikatornya adalah melihat faktor yang berada di atas grafik pesaing.

\subsubsection{Analisis Balanced Scorecard}

Terdapat empat analisis perspektif dalam analisis Balanced Scoreboard yaitu sebagai berikut :

\section{a. Persepktif Pelanggan}

Dalam perspektif pelanggan dilakukan pengukuran kepuasan pelanggan menggunakan metode Customer Satisffaction Index. Pengukuran kepuasan konsumen berdasarkan ke10 atribut dalam penelitian ini. Sebelum melakukan pengukuran kepuasan konsumen, peneliti terlebih dahulu menganalisis important dan performance dari masing-masing 10 atribut.

Pengukuran CSI menggunakan skala likert 5 angka yaitu sangat puas, puas, netral, tidak puas, dan sangat tidak puas. Important dan performance konsumen diperoleh dari penyebaran kuisioner terhadap produk kecap Cemara UKM Cemara Food.

Terdapat empat langkah dalam perhitungan Customer Satisffaction IndexI, yaitu :

1) Menentukan Mean Important Score (MIS) dan Mean Satisffaction Index (MSS). Nilai ini didapat dari rata-rata tingkat kepentingan dan kinerja tiap responden.

$$
\begin{aligned}
\text { MIS } & =\frac{\sum_{i=1}^{\mathrm{n}} \mathrm{Xi}}{\mathrm{n}} \\
\mathrm{MSS} & =\frac{\sum_{i=1}^{\mathrm{n}} Y \mathrm{i}}{\mathrm{n}}
\end{aligned}
$$

Keterangan :

$$
\begin{array}{ll}
\mathrm{n} & =\text { jumlah responden } \\
\mathrm{Yi} & =\text { nilai kepentingan atribut } \\
& \text { ke- } \mathrm{i} \\
\mathrm{Xi} & =\text { nilai kinerja atribut ke-i }
\end{array}
$$

2) Membuat Weight Faktors (WF), bobot ini merupakan presentase nilai MIS per atribut terhadap total MIS seluruh atribut.

$$
\mathrm{WF}_{i}=\frac{\mathrm{MIS} i}{\sum^{\mathrm{p}}{ }_{i=1} \mathrm{MISi} i} \times 100 \%
$$

Keterangan :

$$
\begin{array}{ll}
\mathrm{p} & =\text { jumlah atribut kepentingan } \\
\mathrm{i} & =\text { atribut ke-i }
\end{array}
$$

3) Membuat Weight Score (WS), bobot ini merupakan perkalian antara Weight Faktors (WF) dengan Mean Satisffaction Score (MSS)

$\mathrm{WS}_{\mathrm{i}}=\mathrm{WF}_{\mathrm{i}} \times \mathrm{MSS}_{\mathrm{i}}$

Keterangan :

$\mathrm{WS}_{\mathrm{i}} \quad=$ jumlah atribut kepentingan

$\mathrm{WF}_{\mathrm{i}} \quad=$ atribut ke-i

$\mathrm{MSS}_{\mathrm{i}}=$ rata-rata nilai kepuasan

4) Menentukan nilai CSI

$C S I=\frac{M \sum_{i=1}^{\mathrm{p}} \mathrm{WS} \mathrm{i}}{H S} \times 100 \%$

Keterangan :

$\mathrm{p} \quad=$ Atribut kepentingan ke-p

HS = Skala Maksimum yang digunakan (skala 5)

Kriteria indeks kepuasan menggunakan kisaran 0,00 hingga 1,00 (tidak puas hingga sangat puas), yang dapat dilihat pada Tabel 1 .

Tabel 1. Kriteria nilai Customer Satisffaction Index (Amelia, 2006).

\begin{tabular}{cc}
\hline Nilai $C S I$ & Kriteria CSI \\
\hline $0,81-1,00$ & Sangat Puas \\
$0,66-0,80$ & Puas \\
$0,51-0,65$ & Cukup Puas \\
$0,35-0,50$ & Kurang Puas \\
$0,00-0,34$ & Tidak Puas \\
\hline
\end{tabular}

b. Perspektif Keuangan

Parameter pengukuran dalam perspektif keuangan menggunakan analisis finansial perusahaan. Ukuran yang digunakan adalah sebagai berikut :

1) Analisis Keuntungan Perusahaan

Analisis keuntungan perusahaan didapatkan dari selisih antara penerimaan dan 
biaya total yang dikeluarkan oleh perusahaan. Keuntungan perusahaan sama dengan pendapatan usaha UKM Cemara Food.

\section{2) Return On Equity (ROE)}

Return On Equity merupakan rasio antara keuntungan yang didapatkan perusahaan atau juga merupakan total investasi UKM Cemara Food. Hasil perhitungan ROE disajikan dalam bentuk persen. Rumus yang digunakan adalah :

$$
\mathrm{ROE}=\frac{\text { Laba bersih }}{\text { Modal sendiri }} \times 100 \%
$$

Keterangan:

$\begin{array}{ll}\text { ROE } & \text { : Return On Equity } \\ \text { Laba Bersih } & \begin{array}{l}\text { UKM Cemara Food } \\ \text { : Keuntungan bersih } \\ \text { UKM Cemara Food }\end{array} \\ \text { Modal Sendiri } & \begin{array}{l}\text { : Modal yang } \\ \text { dikeluarkan UKM Cemara } \\ \text { Food }\end{array}\end{array}$

c. Perspektif Bisnis Internal

Pengukuran dalam perspektif bisnis internal meliputi :

1) Pertumbuhan Volume Penjualan

Volume penjualan perusahaan diketahui dari hasil produksi kecap Cemara untuk periode setiap tahunya. Dari data hasil produksi kecap Cemara pertahunnya dilihat apakah terjadi peningkatan ataupun penurunan jumlah produksi kecap Cemara.

2) Kepatuhan Terhadap Regulasi

Parameter penilaian perusahaan yang patuh terhadap regulasi adalah dengan adanya Standard Operating Procedure yang digunakan dalam kegiatan produksi pada UKM Cemara Food sesuai dengan peraturan kementerian perindustrian, kementerian kesehatan dan BPOM. Aspek kepatuhan terhadap peraturan atas SOP dijelaskan secara deskriptif.

d. Perspektif Perkembangan dan

Pembelajaran

Indikator dalam pengukuran perspektif perkembangan dan pembelajaran adalah melihat bagaimana perhatian dan apresiasi perusahaan untuk jangka panjang terhadap orang-orang dalam organisasi serta infrastruktur perusahaan. Berikut merupakan aspek yang dinilai, yaitu :
1) Kompensasi Karyawan

Apresiasi perusahaan terhadap karyawan dapat ditunjukan melaui kompensasi yang diberikan perusahaan. Penilaian yang digunakan adalah dengan melihat apakah terjadi peningkatan atau penurunan karyawan dengan prosentase 0\%-100\%. Analisis kompensasi karyawan dijelaskan secara deskriptif.

2) Pelatihan Karyawan

Pelatihan karyawan diukur berdasarkan keberhasilan UKM Cemara Food dalam memenuhi kebijakan perusahaan mengenai kapan dilakukan pelatihan untuk karyawan. Indikator penilaian adalah dengan melihat peningkatan atau penurunan karyawan dengan prosentase 0\%$100 \%$. Analisis pelatihan karyawan dijelaskan secara deskriptif.

\section{Hasil dan Pembahasan}

\subsection{Kanvas Strategi Kecap Cemara}

Metode kanvas strategi berfungsi untuk mengetahui keberadaan Kecap Cemara diantara pesaing-pesaingnya. Faktor-faktor kompetisi digunakan untuk mengetahui keberadaan Kecap Cemara. Faktor kompetisi yang akan dianalisis meliputi harga, rasa, desain kemasan, volume, warna, kekentalan, ekonomis, kesesuaian produk, kemudahan mendapatkan, dan kemampuan produk dalam menyedapkan. Hasil kanvas strategi dapat dilihat dalam grafik kanvas pada Gambar 1. berikut ini :

Adapun cara membaca grafik kanvas strategi yang dijelaskan menurut Kim dan Renee (2005), adalah sebagai berikut:

a. Kurva nilai Kecap Cemara bertemu dengan kurva nilai pesaingnya, kondisi tersebut menunjukan bahwa Kecap Cemara terperangkap pada kompetisi Samudera Merah.

b. Kurva nilai Kecap Cemara terlihat "naikturun-naik-turun" maka hal tersebut menunjukan bahwa perusahaan tersebut tidak memilki strategi yang koheren.

c. Fluktuasi pada kurva juga menunjukan bahwa Cemara Food belum memiliki focus dan divergence dalam kebijakan strateginya. 


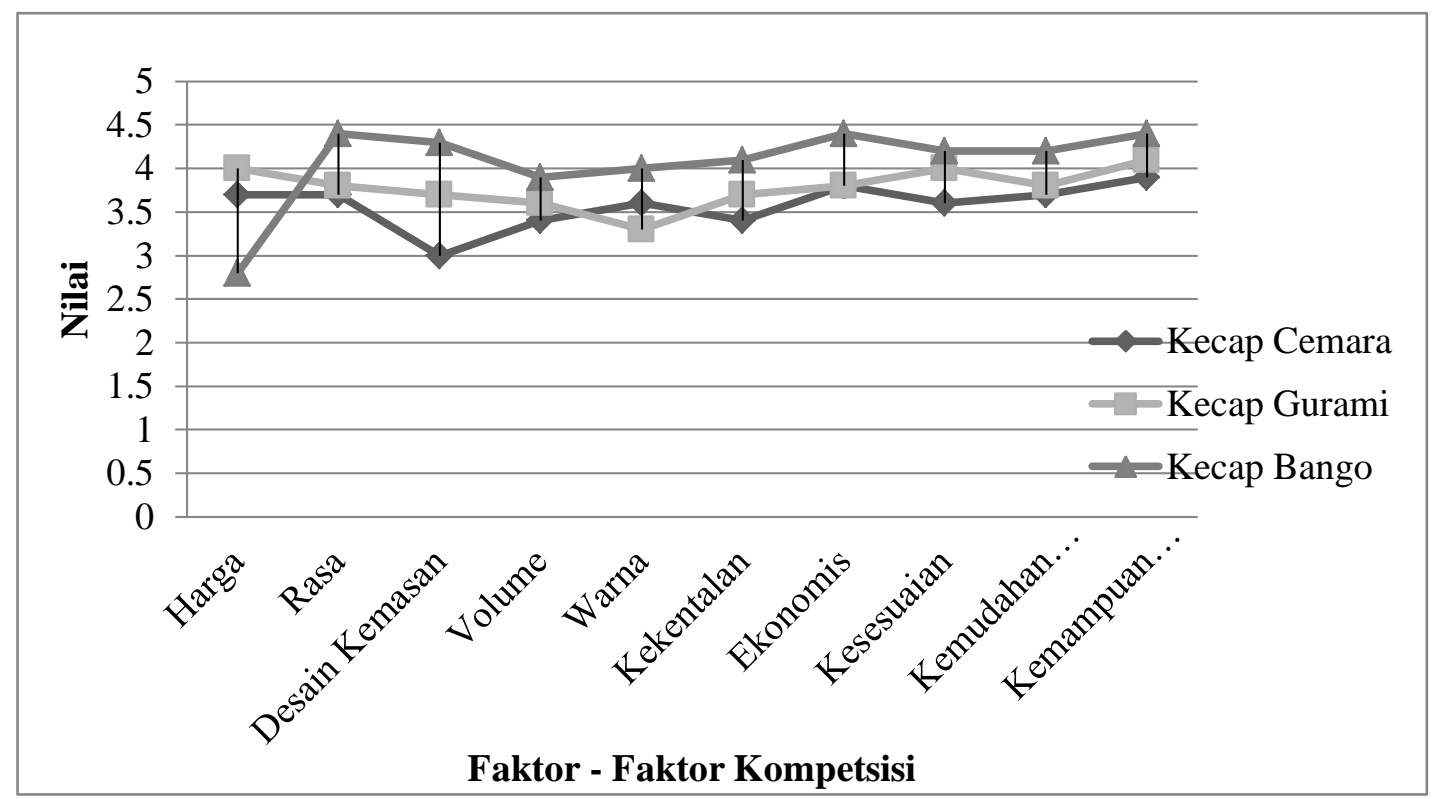

Gambar 1. Kanvas Strategi Kecap Cemara

Adapun cara membaca grafik kanvas strategi yang dijelaskan menurut Kim dan Renee (2005), adalah sebagai berikut:

a. Kurva nilai Kecap Cemara bertemu dengan kurva nilai pesaingnya, kondisi tersebut menunjukan bahwa Kecap Cemara terperangkap pada kompetisi Samudera Merah.

b. Kurva nilai Kecap Cemara terlihat "naikturun-naik-turun" maka hal tersebut menunjukan bahwa perusahaan tersebut tidak memilki strategi yang koheren.

c. Fluktuasi pada kurva juga menunjukan bahwa Cemara Food belum memiliki focus dan divergence dalam kebijakan strateginya.

Berdasarkan grafik kanvas strategi pada Gambar 1 yang menunjukan kondisi persaingan pasar antara ketiga produk yaitu kecap merk Cemara, Gurami dan Bango diketahui bahwa kecap Cemara milik Cemara Food berada dalam posisi samudera merah. Kondisi tersebut menunjukan bahwa strategi yang diterapkan oleh perusahaan belum memiliki focus. Untuk menerapkan perbaikan strategi usaha berdasarkan Blue Ocean Strategi, perusahaan perlu melakukan langkah-langkah strategis untuk pengembangan kecap Cemara dengan tujuan untuk berpindah dari kondisi samudera merah ke samudera biru.

Oleh karena itu untuk membuat sebuah kanvas strategi diperlukan kerangka kerja 4 langkah yang hendaknya dilakukan oleh perusahaan untuk menuju Blue Ocean Strategi.
Berikut ini kerangka kerja yang diformulasikan oleh peneliti berdasarkan pengamatan pribadi peneliti dan juga berasal dari saran konsumen yang menjadi responden penelitian :

\section{a. Hapuskan:}

Tidak ada faktor yang perlu dihapuskan

b. Ciptakan :

1) Menambahkan alat/media promosi.

2) Kemasan, yang bukan berasal dari botol bekas. Ciptakan kemasan dari botol plastik.

3) Membuka gerai/toko khusus yang menjual produk Cemara Food.

4) Volume kemasan yang lebih bervariasi.

5) Sistem kritik dan saran bagi konsumen.

6) Produk dengan standar premium, khusus untuk menjangkau segment kelas atas.

7) Buku/Dokumen berupa SOP perusahaan meliputi pedoman produksi, keuangan dan pemasaran sebagai acuan perusahaan Cemara Food.

c. Kurangi :

1) Harga yang terlalu tinggi.

2) Bahan baku yang dapat menyebabkan kualitas kecap menurun.

d. Tingkatkan :

1) Cita rasa kecap.

2) Konsistensi warna kecap yang pekat merupakan harapan konsumen.

3) Kebersihan dan higienitas produk.

4) Kualitas alat produksi untuk mengejar efisiensi dan mendukung perluasan pangsa pasar. 


\subsection{Analisis Kinerja Perusahaan dengan Balanced Scorecard}

Pendekatan Balanced Scorecard digunakan untuk menganalisis kinerja perusahaan dengan menggunakan indikator berupa 4 perspektif. Berikut ini merupakan hasil analisis kinerja perusahaan dengan pendekatan Balanced Scorecard.

\subsubsection{Perspektif Pelanggan}

Customer Satisfaction Index

Berdasarkan pada Tabel 2. tersebut diketahui bahwa nilai kepuasan konsumen terhadap kecap Cemara adalah sebesar 0,71 atau $71 \%$, angka tersebut menandakan bahwa secara keseluruhan konsumen Puas terhadap atribut kecap Cemara. Kriteria tingkat kepuasan Customer Satisfaction Index sudah dijelaskan sebelumnya pada tabel 4. Untuk kriteria kepuasan CSI kecap Cemara berada pada tingkat selang
Puas $(0,66-0,80)$ sehingga perusahaan harus terus meningkatkan kinerjanya agar kepuasan konsumen meningkat ke kriteria diatasnya yaitu Sangat Puas maupun hingga nilai Customer Satisfaction Index konsumen kecap Cemara mencapai $100 \%$.

Berdasarkan nilai Customer Satisfaction Index tersebut penting bagi Cemara Food untuk meningkatkan kualitas dan performa kecap Cemara karena menurut Kotler (2002), terdapat perbedaan antara konsumen yang menyatakan "Puas" dengan "Sangat Puas" , konsumen yang menyatakan "Puas" saja akan mudah direbut oleh pesaing apabila pesaing dari produk kecap Cemara menawarkan sesuatu yang lebih dibanding kecap Cemara. Sedangkan konsumen yang menyatakan "Sangat Puas" mereka akan cenderung untuk membanggakan produk/jasa yang dikonsumsinya serta tak akan mudah beralih pada produk milik perusahaan/merk lainnya.

Tabel 2. Customer Satisfaction Index Kecap Cemara.

\begin{tabular}{|c|c|c|c|c|c|c|c|c|}
\hline \multirow{2}{*}{ Atribut } & \multirow{2}{*}{$\mathbf{Y i}$} & \multirow{2}{*}{$\mathbf{X i}$} & \multirow{2}{*}{ MIS } & \multirow{2}{*}{ MSS } & \multicolumn{2}{|c|}{ Dalam Persen (\%) } & \multicolumn{2}{|c|}{ Dalam Desimal } \\
\hline & & & & & WF & WS & WF & WS \\
\hline Harga & 149 & 147 & 3,73 & 3,78 & 9,59 & 36,75 & 0,10 & 0,37 \\
\hline Rasa & 175 & 148 & 4,38 & 3,70 & 11,27 & 40,70 & 0,11 & 0,41 \\
\hline Desain Kemasan & 140 & 120 & 3,50 & 3,00 & 9,01 & 27,00 & 0,09 & 0,27 \\
\hline Volume & 136 & 135 & 3,40 & 3,48 & 8,76 & 30,38 & 0,09 & 0,30 \\
\hline Warna & 149 & 142 & 3,73 & 3,65 & 9,59 & 35,50 & 0,10 & 0,36 \\
\hline Kekentalan & 163 & 136 & 4,08 & 3,40 & 10,50 & 34,00 & 0,10 & 0,34 \\
\hline Ekonomis & 161 & 150 & 4,03 & 3,85 & 10,37 & 37,50 & 0,10 & 0,38 \\
\hline Kesesuaian & 154 & 144 & 3,85 & 3,60 & 9,92 & 36,00 & 0,10 & 0,36 \\
\hline Kemudahan Mendapatkan & 151 & 146 & 3,77 & 3,75 & 9,72 & 36,50 & 0,10 & 0,37 \\
\hline $\begin{array}{l}\text { Kemampuan } \\
\text { Menyedapkan }\end{array}$ & 175 & 156 & 4,37 & 3,90 & 11,27 & 42,90 & 0,11 & 0,43 \\
\hline Total & & & $\mathbf{3 8 , 8 3}$ & 35,60 & 100 & 357,23 & 1,00 & 3,57 \\
\hline
\end{tabular}

\subsubsection{Perspektif Keuangan}

a. Keuntungan Perusahaan

Tabel 3. Keuntungan Perusahaan Selama Periode 2014-2015.

\begin{tabular}{cc}
\hline Tahun & Keuntungan \\
\hline 2014 & Rp 91.808 .685 \\
2015 & Rp 98.340.525 \\
\hline
\end{tabular}

Analisis keuntungan perusahaan digunakan dalam perspektif keuangan dan dilihat apakah terjadi kenaikan atau penurunan keuntungan perusahaan. Berikut ini merupakan hasil perhitungan keuntungan perusahaan pada periode tahun 2014-2015, dengan perhitungan awal berdasarkan rata-rata penerimaan per bulan dan dengan estimasi keuntungan sebesar $20 \%$ dari penerimaan per bulan.

Berdasarkan pada Tabel. 3 tersebut diketahui bahwa keuntungan pada tahun 2015 meningkat sebesar Rp 6.531 .840 dari tahun 2014. Peningkatan keuntungan Cemara Food mencapai 7,11 \% dari tahun 2014-2015. Peningkatan keuntungan mengindikasikan pertumbuhan positif perusahaan.

b. ROE (Return On Equity)

Return on equity (ROE) disebut juga dengan laba atas equity. Analisis ROE merupakan rasio dari perputaran total asset yang 
mengkaji sejauh mana suatu perusahaan mempergunakan sumber daya yang dimiliki untuk mampu memberikan laba atas ekuitas perusahaan (Fahmi, 2014). Analisis ROE juga berfungsi bagi para pemegang saham untuk mengetahui seberapa tinggi tingkat pengembalian investasi (Khoiriyah, 2015). Berikut ini merupakan tabel perhitungan ROE kecap Cemara pada perusahaan Cemara Food pada rata-rata penggunaan modal produksi per bulan berdasarkan hasil wawancara dengan $\mathrm{Ny}$. Sumiati selaku pemilik perusahaan. Pada Tabel. 4 diketahui bahwa hasil analisis return on equity adalah sebesar 16,4 persen yang berarti bahwa tingkat pengembalian investasi usaha kecap cemara sebesar $16,4 \%$ rata-rata per bulan. Berdasarkan hasil perhitungan ROE tersebut bahwa setiap pengeluaran modal investasi sebesar Rp1.000,00 maka akan diperoleh pengembalian investasi sebesar Rp1.640,00 (Khoiriyah, 2015). Apabila dilihat berdasarkan hasil analisis tersebut, maka usaha yang dijalankan dinilai menguntungkan. Angka ROE yang semakin tinggi memberikan indikasi bagi para pemegang saham bahwa tingkat pengembalian investasi makin tinggi, sedangkan angka ROE dapat dikatakan baik apabila $>15 \%$ (Brigham dan Houston, 2007).

\section{c. Analisis R/C Ratio}

Analisis $\mathrm{R} / \mathrm{C}$ ratio diperoleh dari rasio antara total penerimaan dan biaya total.

Tabel 5. Rata-rata Keuntungan per Bulan Usaha Pembuatan Kecap Cemara.

\begin{tabular}{llc}
\hline No. & Uraian & Jumlah (Rp) \\
\hline $\mathbf{1}$ & Total Penerimaan / Bulan & 40.990 .000 \\
$\mathbf{2}$ & Total Biaya / Bulan & 32.775 .756 \\
\hline \multicolumn{2}{c}{ Total Keuntungan / Bulan } & $\mathbf{8 . 2 1 4 . 2 4 4}$ \\
\hline
\end{tabular}

Total penerimaan usaha kecap Cemara yang diterima oleh perusahaan adalah sebesar Rp40.990.000,00 dengan total biaya yang dikeluarkan perusahaan adalah sebesar Rp32.775.756,00. Sehingga diperoleh hasil R/C ratio sebesar 1,25 yang artinya bahwa usaha produksi kecap Cemara milik Cemara Food sudah menguntungkan. Dikatakan menguntungkan karena nilai R/C Ratio $\geq 1$ dan dapat disimpulkan bahwa usaha kecap cemara layak dan menguntungkan untuk dijalankan dan dikembangkan.

\subsubsection{Perspektif Bisnis Internal}

a. Produksi Perusahaan
Indikator pertama yang digunakan dalam perspektif bisnis internal adalah dengan melihat produksi perusahaan. Peningkatan produksi perusahaan dilihat berdasarkan terjadinya kenaikan atau penurunan pada produksi kecap Cemara.

Tabel 6. Rata-rata produksi kecap Cemara pertahun periode 2014-2015.

\begin{tabular}{lccc}
\hline $\begin{array}{l}\text { Tahun } \\
\text { Ukuran }\end{array}$ & $\begin{array}{c}\mathbf{2 0 1 4} \\
\text { (Kemasan) }\end{array}$ & $\begin{array}{c}\mathbf{2 0 1 5} \\
\text { (Kemasan) }\end{array}$ & $\begin{array}{c}\text { Presentase } \\
\text { (Naik/Turun) }\end{array}$ \\
\hline $850 \mathrm{ml}$ & 2088 & 2200 & Naik 5,4\% \\
$650 \mathrm{ml}$ & 1386 & 1498 & Naik 8\% \\
$135 \mathrm{ml}$ & 388 & 500 & Naik 28,8\% \\
Sachet & 683 & 795 & Naik 16,3\% \\
\hline
\end{tabular}

Angka volume produksi perusahaan yang semakin bertambah pada tiap periode/tahun menandakan terjadinya pertumbuhan positif perusahaan ( Heizer dan Render, 2009). Sehingga berdasarkan teori dan data produksi kecap Cemara periode 2014-2015 yang mengalami peningkatan pada masing-masing kemasan, hal tersebut merupakan indikator bahwa eksistensi kecap Cemara milik perusahaan Cemara Food mengalami pertumbuhan positif, meskipun presentase dan kuantitasnya belum meningkat secara signifikan.

b. Kepatuhan Perusahaan Terhadap Regulasi dan Kesesuaian dengan SOP

Produk kecap Cemara telah terdaftar dan tersertifikasi oleh Dinkes $(+15 \%)$ dan Badan Lingkungan Hidup $(+10 \%)$, perusahaan juga telah memiliki NPWP $(+10 \%)$ dari Disperindag Kab. Blitar dan telah tersertifikasi halal oleh MUI (+15\%). Namun Cemara Food belum memiliki SOP(-25\%) yang digunakan untuk menjalankan perusahaan dan kegiatan produksi kecap Cemara. Kondisi tersebut tentu merupakan sesuatu yang kurang baik, karena menurut Wanabakti (2011), tujuan dibuatnya pedoman berupa SOP adalah untuk menjaga konsistensi kerja yang akan memberikan dampak pada konsistensi kualitas produk yang homogen, pun juga untuk menghindari terjadinya kesalahan dan kegagalan serta sebagai parameter mutu produk. Perusahaan juga belum memiliki sertifikasi atau legalitas dari BPOM (25\%). Berdasarkan teori tersebut tentu kinerja Cemara Food dalam memproduksi kecap Cemara juga akan memiliki hambatan. Presentase penilaian yang diberikan terhadap kepatuhan adalah sebesar $50 \%$ berdasarkan kriteria penilaian yang ditentukan oleh peneliti. 


\subsubsection{Perspektif Pembelajaran Pertumbuhan}

dan

Pada perspektif pembelajaran dan pertumbuhan perusahaan, presentase skor yang diberikan peneliti adalah sebesar $70 \%$ berdasarkan kriteria penilaian yang ditentukan oleh peneliti. Presentase tersebut dipengaruhi oleh tingkat pertumbuhan karyawan yang stabil selama kurun waktu 2 tahun $(+10 \%)$ dan manajemen SDM perusahaan yang memberikan apresiasi tinggi pada karyawan $(+10 \%)$. Presentase nilai tertinggi dipengaruhi oleh keberhasilan perusahaan mengeluarkan varian produk baru Kecap Cemara ukuran $135 \mathrm{ml}$ pada tahun 2012, sehingga menyumbangkan penilaian dengan presentase $(+50 \%)$. Nilai tersebut menunjukan meskipun perusahaan masih berskala UKM, namun kinerja serta manajerial organisasi bisnis perusahaan telah cukup berkembang.

\subsubsection{Pemetaan Blue Ocean Strategy dan Balanced Scorecard}

a. Perspektif Pelanggan terhadap Blue Ocean Strategy

1) Penambahan media dan kegiatan promosi akan dapat membuat kecap Cemara semakin dikenal luas oleh konsumen, serta juga dapat mengikat keyakinan konsumen pada kecap Cemara dengan eksistensi promosi yang dilakukan oleh perusahaan.

2) Penggunaan kemasan original yang bukan berasal dari botol kemasan rekondisi akan dapat menjaga keyakinan konsumen akan produk yang higienis dan memiliki ciri khas.

3) Gerai toko resmi kecap Cemara yang menjual berbagai jenis kecap Cemara dan aneka produk milik Cemara Food akan memudahkan konsumen dalam mendapatkan kecap Cemara dan juga sebagai sarana menjaga kedekatan produk/produsen dengan pelanggan.

4) Keragaman jenis ukuran kemasan akan memberikan banyak pilihan untuk pelanggan sesuai dengan kebutuhan dan seleranya.

5) Fitur kritik dan saran untuk produk akan membantu perusahaan dalam mengevaluasi kinerja produk, juga sebagai sarana untuk memberi ruang aspirasi konsumen.
6) Produk baru kecap Cemara berstandar premium akan membantu perusahaan untuk memperluas dan menjangkau segment konsumen baru.

b. Perspektif Keuangan terhadap Blue Ocean Strategy

1) Kegiatan promosi yang semakin gencar akan memberikan peluang untuk meningkatkan jumlah penjualan kecap Cemara.

2) Gerai toko khusus yang menjual produk Cemara Food termasuk kecap Cemara akan memudahkan konsumen melakukan pembelian dan juga akan mengurangi biaya pemasaran.

3) Alat produksi yang diperbarui akan membantu dalam meningkatkan efisiensi produksi, sehingga penggunaan waktu dan biaya akan menurun, manfaatnya adalah keuntungan akan naik.

4) Produk baru kecap Cemara yang memiliki standar premium tentu juga memiliki harga diatas kecap Cemara yang biasanya, hal ini akan menjadikan peluang bagi perusahaan untuk meningkatkan pendapatanya.

c. Perspektif Bisnis Internal terhadap Blue Ocean Strategy

1) Kebijakan menjajaki pasar baru sebagai tujuan pemasaran akan memperbesar peluang peningkatan keuntungan perusahaan dan pertumbuhan bisnis perusahaan.

2) Fokus perusahaan yang hanya memperkenalkan kecap Cemara kemasan $135 \mathrm{ml}$ di wilayah Sidoarjo membuat produksi pada kemasan $135 \mathrm{ml}$ naik memiliki presentase kenaikan paling tinggi.

3) Perlu adanya peningkatan kualitas alat produksi yang masih tradisional dengan tujuan untuk mencapai efisiensi produksi semaksimal mungkin. Karena selain dari produksi yang meningkat, pertumbuhan perusahaan juga dilihat dari keuntungan yang bertambah setiap tahun/periodenya.

d. Perspektif Pembelajaran dan Pertumbuhan terhadap Blue Ocean Strategy

1) Meningkatkan kualitas SDM perusahaan dengan pelatihan dan pendidikan baik yang berkaitan dengan penguasaan 
teknologi maupun karakteristik konsumen.

2) Dengan keterbukaan perusahaan atas evaluasi kritik dan saran dari konsumen mengenai produk, maka akan terjadi proses pembelajaran dan perkembangan karena terjalinya kedekatan komunikasi antara produsen dan konsumen.

3) Kreativitas dan ide akan terus mengalir dari setiap karyawan seiring dengan tertampungnya aspirasi dan proses transfer pengetahuan dan keahlian dari karyawan senior kepada junior.

4) Tim kerja yang solid akan tumbuh bukan pada saat fokus target kerja adalah menyesuaikan selera pasar, melainkan pada tumbuhnya kualitas, kreativitas dan apresiasi terhadap kinerja karyawan.

\section{Kesimpulan}

a. Analisis kinerja Perusahaan

1) Perspektif Keuangan : Likuiditas keuangan dan penggunaan modal perusahaan sudah baik dengan indikator $\mathrm{R} / \mathrm{C}$ ratio sebesar 1,25 , nilai $\mathrm{ROE}$ sebesar $16,4 \%$ dan terjadi peningkatan produksi dari tahun 2014-2015 sebesar 7,11\%.

2) Perspektif Konsumen : Nilai CSI sebesar $0,71(71 \%)$ yang berarti bahwa tingkat kepuasan konsumen pada kecap Cemara masih belum maksimal, sehingga harus ditingkatkan hingga level "Sangat Puas" $(>80 \%)$.

3) Perspektif Bisnis Internal : Terjadinya peningkatan kapasitas produksi rata-rata kecap Cemara dari tahun 2014-2015 menandakan terjadinya pertumbuhan positif perusahaan dan merupakan indikator semakin meningkatnya eksistensi produk Kecap Cemara.

4) Perspektif Pembelajaran dan Perkembangan : Presentase nilai kepatuhan perusahaan terhadap regulasi hanya sebesar $50 \%$ disebabkan ketiadaan SOP perusahaan yang juga menjadi faktor penyebab produk tidak memiliki sertifikasi dari BPOM.

b. Rekomendasi strategi pengembangan kecap Cemara berdasarkan pendekatan Blue Ocean Strategy terhadap Balanced Scorecard berurutan sesuai prioritas terdekat yang dapat diselesaikan adalah sebagai berikut :
1) Melakukan kerjasama dengan distributor di luar Kab. Blitar untuk mempromosikan dan memasarkan kecap Cemara.

2) Memperbarui atau memodifikasi alat dan sarana produksi untuk meningkatkan efisiensi dan volume produksi perusahaan.

3) Mengolah limbah kecap menjadi produk yang memiliki nilai ekonomis sehingga dapat menjadi tambahan pendapatan perusahaan, misalnya menjadi tauco.

4) Melakukan inovasi pada kemasan, memperbaiki kualitas rasa, warna dan bahan baku kecap untuk meningkatkan $C S I \geq 8 \%$ dalam 2 tahun kedepan.

\section{Daftar Pustaka}

Brigham dan Houston. 2007. Essential of Financial Management. Singapore. Thompson.

Ferrinadewi, Erna. 2008. Merek \& Psikologi Konsumen. Yogyakarta. Graha Ilmu.

Handoko, Tani dan Dharmmesta, Basu Swasta. 2012. Manajemen Pemasaran : Analisis Perilaku Konsumen. Edisi Pertama. Yogyakarta. Universitas Gajah Mada.

Heizer, Jay dan Render, Barry. 2009. Manajemen Operasi. Buku 1. Edisi 9. Jakarta. Salemba Empat.

Hermawan, Sigit. 2013. Akutansi Perusahaan Manufaktur. Yogyakarta. Graha Ilmu.

Ichsan, Muhammad., Sukarno, Edy., dan Yuwono, Sony. 2007. Petunjuk Praktis Penyusunan Balanced Scorecard. Jakarta. Gramedia Pustaka Utama.

Khoiriyah, Lailiyatul. 2015. Strategi Pengembangan Usaha Sayuran Organik Suka Karya Garden Dengan Pendekatan Blue Ocean Strategy Dan Balanced Scorecard. Skripsi. Jurusan Sosial Ekonomi Pertanian. Fakultas Pertanian. Universitas Brawijaya.

Kim, W. Chan dan Mauborgne, Renee. 2005. Blue Ocean Strategi. Boston : Harvard. Deterjemahkan oleh : Serambi Ilmu Semesta. Jakarta.

Kotler, Philip. 2002. Marketing Management : The Millennium Edition. New Jersey. Upper Saddle River. 
Norton David P . dan Kaplan Robert S. 2004. Menerapkan Strategi Menjadi Aksi : Balanced Scorecard. Jakarta. Erlangga.

Olson, Jerry dan Peter, Paul J. 2014. Perilaku Konsumen dan Strategi Pemasaran. Edisi 9. Buku 2. Jakarta. Salemba empat.

Sedarmayanti, Hj. dan Hidayat, Syarifuddin. 2002. Metodologi Penelitian. Bandung. Mandar Maju

Sugiyono. 2013. Metode Penelitian Kuantitatif, Kualitatif, dan $R \& D$. Bandung. Alfabeta.

Sunyoto, Danang. 2013. TEORI, KUISIONER \& ANALISIS DATA: Untuk Pemasaran dan Perilaku Konsumen. Yogyakarta. Graha Ilmu.

Wanabakti, Angih dan Dwihardo, Nelman. 2011 Pengaruh Pelatihan, Penerapan Sop, Reward System, Lingkungan Kerja Dan Peralatan Terhadap Produktivitas Teknisi. Skripsi. Universitas Hasanuddin Makassar. 